\title{
Nonirritant concentrations and amount of active ingredient in drug patch tests optimal concentrations for DPTs
}

\author{
Delphine Brajon ${ }^{1}$, Sophie Menetre ${ }^{2}$, Julie Waton ${ }^{1}$, Claire Poreaux ${ }^{1}$, Annick Barbaud ${ }^{1 *}$ \\ From 6th Drug Hypersensitivity Meeting (DHM 6) \\ Bern, Switzerland. 9-12 April 2014
}

\section{Background}

Drug patch tests (DPTs) with medications suspected of causing an allergic reaction represent a method of diagnostic testing that is low risk, as DPTs can reproduce delayed hypersensitivity to drugs and entail only a moderate re-exposure of patients to potential offending drugs. We assessed the non-irritating concentration of DPTs to determine the amount of active ingredient (AI) contained in the drugs used in the tests.

\section{Method}

From a retrospective, single-center study of all patients treated during a 6-year period for etiological investigations following a drug eruption, each potentially responsible drug was tested from the commercially available preparation diluted to $30 \%$ of its concentration in water, petrolatum, or alcohol. Data collection was performed with a customized computer database. For each type of DPT studied, the numbers of positive and negative tests were recorded. The amount of AI contained in the DPT (as a percentage) was then calculated after weighing each tablet.

\section{Results}

Of the 5,558 DPTs studied, all were nonirritant. The average concentration of AI was 9.8\%; $25 \%$ of DPTs had an AI concentration less than $2 \%$, and $25 \%$ displayed an AI concentration above $16 \%$. The AI concentration ranged from $0.05 \%$ (digoxin) to $30 \%$ (paracetamol lyophilisate).

\section{Discussion}

The actual concentrations of the AI in DPTs done at $30 \%$ of the commercially available form varied from

'Department of Dermatology, Brabois Hospital, France

Full list of author information is available at the end of the article
$0.05 \%$ to $27.08 \%$ when tablets were used. Any report of the results of a DPT must give the exact concentration of the AI applied.

\section{Conclusion}

These data provide thresholds for the non-irritating concentration of 89 different drugs, and will help to standardize DPT methods.

\section{Authors' details}

${ }^{1}$ Department of Dermatology, Brabois Hospital, France. ${ }^{2}$ Department of

Pharmacy, Brabois hospital, France.

Published: 18 July 2014

doi:10.1186/2045-7022-4-S3-P1

Cite this article as: Brajon et al:: Nonirritant concentrations and amount of active ingredient in drug patch tests optimal concentrations for DPTs. Clinical and Translational Allergy 2014 4(Suppl 3):P1.

Submit your next manuscript to BioMed Central and take full advantage of:

- Convenient online submission

- Thorough peer review

- No space constraints or color figure charges

- Immediate publication on acceptance

- Inclusion in PubMed, CAS, Scopus and Google Scholar

- Research which is freely available for redistribution

Submit your manuscript at www.biomedcentral.com/submit 